\title{
GENETIC GAINS AND SELECTION ADVANCES OF THE UENF-14 POPCORN POPULATION $^{1}$
}

\author{
AMANDA GONÇALVES GUIMARÃES ${ }^{2 *}$, ANTÔNIO TEIXEIRA DO AMARAL JÚNIOR ${ }^{2}$, VALTER JÁRIO DE \\ LIMA $^{2}$, JHEAN TORRES LEITE ${ }^{2}$, CARLOS ALBERTO SCAPIM ${ }^{3}$, MARCELO VIVAS $^{2}$
}

\begin{abstract}
Recurrent selection can generate successive gains for characters of economic interest without causing genetic narrowing in the population. However, it has rarely been used in breeding programs in popcorn, especially when using full-sibling progenies to generate more expressive gains. The objective of this study was to estimate the genetic gain of the UENF-14 popcorn population through recurrent selection, and verify the evolution of the gains between the selection cycles four and eight. A total of 200 full-sibling progenies were evaluated in randomized blocks arranged in eight sets within three replicates in two environments; each set containing twenty-five progenies and six controls (selection cycles 4, 5, 6 and 7 of the UENF-14, BRS-Angela and IAC-125). The average height, prolificacy, 100-grain weight, ear weight, grain yield, and grain popping expansion of the plants were evaluated. In the selection of the thirty superior progenies for the eighth cycle, the Mulamba and Mock selection index was used, which generated estimated genetic gains of 4.60 for grain yield and $3.61 \%$ for popping expansion. The grain yield increased $111.99 \mathrm{~kg} \mathrm{ha}^{-1}$ and the popping expansion increased $1.75 \mathrm{~mL} \mathrm{~g}^{-1}$ per cycle. The evolution of the cycles resulted in an accumulated genetic gain for the main characters of economic importance, allowing the prediction of success in the continuity of the recurrent selection.
\end{abstract}

Keywords: Selection index. Recurrent selection. Zea mays L..

\section{GANHOS GENÉTICOS E AVANÇOS SELETIVOS NA POPULAÇÃO UENF-14 DE MILHO-PIPOCA}

RESUMO - A seleção recorrente embora permita sucessivos ganhos para caracteres de interesse econômico, sem provocar estreitamento genético na população, tem sido raramente utilizada em programas de melhoramento com milho-pipoca, sobretudo em se tratando da estratégia de utilização de progênies de irmãoscompletos, em que são possíveis ganhos mais expressivos. O objetivo deste estudo foi estimar o ganho genético na população UENF-14, de milho-pipoca, por meio de seleção recorrente e averiguar a evolução dos ganhos entre os ciclos quatro e oito de seleção. Foram avaliadas 200 progênies de irmãos-completos, em blocos casualizados, com arranjos em sets dentro de três repetições em dois ambientes, no total de oito sets, sendo que cada set continha vinte e cinco progênies e seis testemunhas (ciclos 4, 5, 6 e 7 de seleção em UENF-14, BRS Angela e IAC 125). Avaliou-se a altura média da planta, prolificidade, peso de cem grãos, peso de espiga, produtividade de grãos e capacidade de expansão. Na seleção das trinta progênies superiores para o oitavo ciclo, foi utilizado o índice de seleção Mulamba e Mock, que proporcionou ganhos genéticos estimados de 4,60 e 3,61\%, respectivamente, para produtividade de grãos e capacidade de expansão. Houve incremento de $111,99 \mathrm{~kg} \mathrm{ha}^{-1}$ e de $1,75 \mathrm{~mL} \mathrm{~g}^{-1}$, por ciclo, para a produtividade de grãos e capacidade de expansão, nesta ordem. A evolução dos ciclos revelou ganho genético acumulado para os principais caracteres de importância econômica da cultura, possibilitando a antevisão de sucesso, na continuidade da seleção recorrente.

Palavras-chave: Índice de seleção. Seleção recorrente. Zea mays L..

\footnotetext{
*Corresponding author

${ }^{1}$ Received for publication in $07 / 22 / 2016$; accepted in $07 / 17 / 2017$.

Part extracted from the doctoral thesis of the first author.

${ }^{2}$ Center of Sciences and Agricultural Technologies, Universidade Estadual do Norte Fluminense Darcy Ribeiro, Campos dos Goytacazes, RJ, Brazil; amandagguimaraes@yahoo.com.br, amaraluenf@gmail.com, valter_jario@hotmail.com, torresjhean@gmail.com, mrclvivas@hotmail.com.

${ }^{3}$ Department of Agronomy, Universidade Estadual de Maringá, PR, Brazil; cascapim@uem.br.
} 


\section{INTRODUCTION}

Popcorn is a very popular food in Brazil; however, its production is below the potential demand, as evidenced by the large volume of imported grains (FREITAS JÚNIOR et al., 2009). In this context, the development and release of new popcorn cultivars are essential to mitigate the dependence on genotypes from foreign countries, and meet the demand of producers and consumers, offering them cultivars and products with the characters of interest.

Similar to most characters of agronomic interest, the popcorn yield and popping expansion are controlled by several genes (ZEIGLER, 2001), which makes it difficult to achieve success in a single selective cycle. Therefore, the recurrent selection methodology is used repeatedly, selecting the best genotypes in each cycle, in order to obtain gains at the end of each selection process (HALLAUER; MIRANDA FILHO; CARENA, 2010). As a consequence, an increase in the frequency of favorable alleles is expected, improving the main characters without exhausting the genetic variability of the population (HALLAUER; MIRANDA FILHO; CARENA, 2010; RAMALHO et al., 2012). Intra-population breeding is a feasible option due to its easy execution, and positive applicability to obtain genetic gains (PEREIRA; AMARAL JÚNIOR, 2001; HALLAUER; MIRANDA FILHO; CARENA, 2010). Among the strategies used for this, is the recurrent selection among full-sibling progenies; although it is a laborious procedure, it has high efficiency in obtaining considerable genetic progress for grain yield and popping expansion (PEREIRA; AMARAL JÚNIOR, 2001; HALLAUER; CARENA, 2009).

Breeding programs constantly search for cultivars with superior performance for the various characters of interest, in order to meet the demand of both producers and consumers; in the case of popcorn, yield and popping expansion, respectively. However, this is not an easy task; the degree of genetic association between characters must be considered for the application of efficient methods that result progressive selection gains. The negative correlation between grain popping expansion and grain yield in popcorn (HALLAUER, 2001; CABRAL et al., 2016) is a disadvantage because it does not allow the direct selection of the best individuals for both characters, which hinders the obtaining of superior cultivars. A viable alternative is the use of selection indices, which allow to obtain genetic gains for the characters of interest with others that the breeder prioritizes in the selective process (CRUZ; REGAZZI; CARNEIRO, 2012).

These indices constitute a multivariate technique that associates the information on the characters of agronomic interest with the genetic properties of the evaluated population. According to Santos et al. (2007) and Freitas et al. (2014), the Mulamba and Mock index (1978) resulted in superior gains for grain popping expansion and yield than the other indices evaluated. This index is based on the sum of ranks and consists in classifying the genotypes, depending on each one of the characters in favorable order of improvement; then, the orders of each genotype, referring to each character, are added (CRUZ; REGAZZI; CARNEIRO, 2012).

Information on recurrent selection in popcorn are scarce, thus, the objective of this study was to estimate the genetic gain of the UENF-14 popcorn population in the eighth cycle of intra-population recurrent selection by selection index, especially for the characters of commercial interest (grain yield and popping expansion), and verify the evolution of the gains in successive selection cycles.

\section{MATERIAL AND METHODS}

Obtaining and evaluation of progenies of the eighth cycle of the UENF-14 popcorn population

The study population consisted of 200 full-sibling progenies, obtained in the eighth cycle of the popcorn variety UENF-14 (AMARAL JÚNIOR et al., 2013). In order to obtain these progenies, one hundred five-meter rows were sowed in April 2013, using recombinant seeds of the seventh recurrent selection cycle of the UENF-14, in an area of the Antônio Sarlo State Agricultural High School, in Campos dos Goytacazes in the state of Rio de Janeiro (RJ), Brazil.

The competition tests were conducted in the 2013/2014 crop season, in two environments: Antônio Sarlo State Agricultural High School $-21^{\circ} 45^{\prime} \mathrm{S}, 41^{\circ} 20^{\prime} \mathrm{W}$, altitude of $11 \mathrm{~m}$, and average annual temperature of $23{ }^{\circ} \mathrm{C}$ - and PESAGRO-Rio experimental station, in Barra do Pomba Island, in Itaocara, RJ-2 $1^{\circ} 39^{\prime} \mathrm{S}, 42^{\circ} 04^{\prime} \mathrm{W}$, altitude of $60 \mathrm{~m}$, and average annual temperature of $22.5^{\circ} \mathrm{C}$.

The experimental design was randomized blocks, arranged in eight sets within three replicates in two environments; each set containing twenty-five full-sibling progenies and six controls (selection cycles 4, 5, 6 and 7 of UENF-14, BRS-Angela and IAC-125). The plot consisted of a three-meter row, with $0.90 \mathrm{~m}$ between rows and $0.20 \mathrm{~m}$ between plants - sixteen plants per plot. Sowing fertilization consisted of $800 \mathrm{~kg} \mathrm{ha}^{-1}$ of the mineral fertilizer 04-14-08 $\left(\mathrm{N}-\mathrm{P}_{2} \mathrm{O}_{5}-\mathrm{K}_{2} \mathrm{O}\right)$. Topdressing consisted of $300 \mathrm{~kg} \mathrm{ha}^{-1}$ of the mineral fertilizer 20-00-20 $\left(\mathrm{N}-\mathrm{P}_{2} \mathrm{O}_{5}-\mathrm{K}_{2} \mathrm{O}\right)$ at 30 days after sowing, plus $260 \mathrm{~kg} \mathrm{ha}^{-1}$ of ammonium sulfate at 45 days after sowing. Weed, pest and disease control was carried out according to the recommendations for the crop (SAWAZAKI, 2001). 
The following characters were evaluated: average plant height $(\mathrm{m})(\mathrm{PH})$, by measuring six plants per plot, from ground to the leaflet insertion; prolificacy (PR), represented by the number of ears per plant; 100-grain weight $(\mathrm{g})(100 \mathrm{GW})$, weight of one hundred grains collected randomly and measured in an analytical balance; ear weight $\left(\mathrm{kg} \mathrm{ha}^{-1}\right)(\mathrm{EW})$, average ear weight produced in the plot; grain yield $\left(\mathrm{kg} \mathrm{ha}^{-1}\right)(\mathrm{GY})$, grain produced in the plot; and grain popping expansion $\left(\mathrm{mL} \mathrm{g}^{-1}\right)(\mathrm{PE})$, volume of $30 \mathrm{~g}$ of grains after taken to the microwave in kraft bag without oil for two minutes, quantified in a $2,000 \mathrm{ml}$ graduated cylinder and the volume divided by 30 .

\section{Statistical Analyzes}

The effect of the set was corrected in the classification of the whole set of progenies, as a function of the average of the controls common to all sets, before the analysis of variance. The average of the controls for each set (ACS) and the overall average of the controls (OAC) were calculated; and the OAC to ACS ratio showed the correction factor for each set. This method was adopted by Ribeiro et al. (2009) for correcting the effect of the set in the subsequent analyzes.

The analysis of variance was performed for the environments and the homogeneity of the residual variances was verified by the relationship between the highest and lowest mean square of the residue (MSR) (GOMES; GARCIA, 2002). Subsequently, joint analysis of variance was conducted, considering the randomized block design, after the correction of the effects of the sets, following the statistical model: $Y_{i j k}=\mu+B / A_{j k}+P_{i}+A_{j}+P A_{i j}+e_{i j k}$, wherein $Y_{i j k}$ is the effect of the progeny $i$ in the environment $j$ and block $k ; \mu$ is the general constant; $B / A_{j k}$ is the effect of the block $k$ within the environment $j$, supposedly independent and normally distributed, with mean zero and constant variance $\sim \operatorname{NID}\left(0,{ }_{\mathrm{B} / \mathrm{A}}^{2}\right) ; P i$ is the random effect of the progeny $i(i=1,2, \ldots 200)$, supposedly independent and normally distributed, with mean zero and constant variance $\sim$ NID $\left(0, \sigma_{\mathrm{P}}^{2}\right) ; A i$ is the fixed effect of the environment $j$ $(j=1,2) ; P A_{i j}$ is the effect of the interaction of the progeny $i$ with the environment $j$, supposedly independent and normally distributed with mean zero and constant variance $\sim \operatorname{NID}\left(0, \sigma_{\mathrm{PA}}^{2}\right)$; and $\mathrm{e}_{\mathrm{ijk}}$ is the effect of the experimental error of the $Y_{i j k}$ observation, supposedly independent and normally distributed, with mean zero and constant variance $\sim \operatorname{NID}\left(0, \sigma^{2}\right)$.

The parameters in the joint analysis were estimated by: I) the coefficient of genetic variation: $\mathrm{CV}_{\mathrm{g}}(\%)=100\left(\frac{\sqrt{\sigma_{\mathrm{g}}^{2}}}{\mu}\right)=100\left(\frac{\sqrt{\frac{\mathrm{MSP}-\mathrm{MSR}}{\mathrm{ar}}}}{\mu}\right)$, wherein $\sigma_{\mathrm{g}}^{2}$ is the genotypic variance between progenies; $\mu$ in the mean; MSP is the mean square of progenies; MSR is the mean square of the residue; $a$ is the number of environments; and $r$ is the number of replicates; II) the coefficient of variation of the experiment: $\mathrm{CV}_{\mathrm{e}}(\%)=100\left(\frac{\sqrt{\sigma_{\mathrm{e}}^{2}}}{\mu}\right)=100\left(\frac{\sqrt{\mathrm{MSR}}}{\mu}\right)$, wherein $\sigma_{\mathrm{e}}^{2}$ is the mean residual variance; and MSR is the mean square of the residue; III) heritability based on the progeny averages: $\quad h^{2}=\frac{\sigma_{\mathrm{g}}^{2}}{\sigma_{\mathrm{p}}^{2}}=\frac{\text { MSP-MSR }}{\text { MSP }}$, wherein $\sigma_{\mathrm{g}}^{2}$ is the genotypic variance between progenies; and $\sigma_{\mathrm{p}}^{2}$ is the phenotypic variance between progenies; and IV) Index of variation: $\mathrm{I}_{\mathrm{v}}=\left(\frac{\mathrm{CV}_{\mathrm{g}}}{\mathrm{CV}_{\mathrm{e}}}\right)$, wherein $\mathrm{CV}_{\mathrm{g}}$ is the coefficient of genetic variation; and $\mathrm{CV}_{\mathrm{e}}$ is the coefficient of variation of the experiment.

The phenotypic $\left(\mathrm{r}_{\mathrm{F}}\right)$ and genotypic $\left(\mathrm{r}_{\mathrm{G}}\right)$ correlations between the pairs of characters related to

the joint analysis were estimated by: $\quad \sqrt{\sigma_{\mathrm{PX} .}^{2} \sigma_{\mathrm{FY}}^{2}}$ and $r \mathrm{r}=\frac{\operatorname{COVG}(\mathrm{X}, \mathrm{Y})}{\sqrt{\sigma_{\mathrm{GX}}^{2} \sigma_{\mathrm{GY}}^{2}}}$, wherein, respectively, $\operatorname{COV}_{\mathrm{P}(\mathrm{X}, \mathrm{Y})}$ and $\mathrm{COV}_{\mathrm{G}(\mathrm{X}, \mathrm{Y})}$ are the estimates of phenotypic and genotypic covariance between the characters $\mathrm{x}$ and $\mathrm{y}$; $\sigma_{\mathrm{PX}}^{2}$. and $\sigma_{\mathrm{GX}}^{2}$. are the estimates of the phenotypic and genotypic variances of the character $\mathrm{x}$; and $\sigma_{\mathrm{PY}}^{2}$ and $\sigma_{\mathrm{GY}}^{2}$ are the phenotypic and genotypic variances of the character $y$.

The selection index Mulamba and Mock (1978) was used for the selection of the thirty progenies for the eighth cycle, with the economic weights suggested by Cruz, Regazzi and Carneiro (2012): genotypic standard deviation (SDg), coefficient of genetic variation $\mathrm{CVg}$ ), variation index (Iv), heritability estimate $\left(\mathrm{h}^{2}\right)$ of each variable, and weights assigned by attempts (WA). In this latter, after several arbitrary attempts, larger weights for the most relevant characters of the popcorn crop was applied. Thus, WAs of 0 (PH), 1 (PR), 1 (100GW), 1 (EW), $5(\mathrm{GY})$, and 10 (PE) were used. All the statistical analyzes were performed using the software GENES (CRUZ, 2013).

The means of the controls of the UENF-14 population, and the predicted means for the eighth cycle in the two environments were estimated by simple linear regression equation, in which the variables grain yield and popping expansion were considered as dependent variables and the cycles as independent variables.

\section{RESULTS AND DISCUSSION}

Population characters and genetic parameters in the eighth selective cycle of UENF-14 
The population characters, measures of genetic parameters, variability, as well as the environmental effect, and data quality of the population evaluated are important for breeders. This information assists them on choosing breeding strategies for the selection of superior genotypes and develop new varieties for producers.
Therefore, the individual analysis of variance of each environment was carried out (Table 1), which showed homogeneity of residual variances - ratio between highest and lowest mean squares of the residue lower than seven (GOMES; GARCIA, 2002) - in all characters; and then, the joint analysis of variance was performed (Table 2 ).

Table 1. Mean square of the residue (MSR), mean, coefficient of variation of the experiment (CVe), and heritability based on the progeny averages $\left(\mathrm{h}^{2}\right)$ of six characters of the UENF-14 popcorn population in the eighth recurrent selection cycle in two environments.

\begin{tabular}{|c|c|c|c|c|c|}
\hline \multirow{4}{*}{ PH } & Environment & MSR & Mean & $\mathrm{CVe}(\%)$ & $\mathrm{h}^{2}$ \\
\hline & Itaocara & 0.02 & 1.9 & 7.79 & 0.59 \\
\hline & Campos dos Goytacazes & 0.03 & 1.41 & 12 & 0.32 \\
\hline & Highest MSR / Lowest MSR & 1.30 & & & \\
\hline \multirow[t]{3}{*}{ PR } & Itaocara & 0.09 & 1.46 & 20.39 & 0.26 \\
\hline & Campos dos Goytacazes & 0.07 & 1.1 & 23.73 & 0.47 \\
\hline & Highest MSR / Lowest MSR & 1.32 & & & \\
\hline \multirow[t]{3}{*}{ 100GW } & Itaocara & 8.47 & 13.72 & 21.21 & 0.22 \\
\hline & Campos dos Goytacazes & 2.81 & 9.56 & 17.55 & 0.48 \\
\hline & Highest MSR / Lowest MSR & 3.00 & & & \\
\hline \multirow[t]{3}{*}{ EW } & Itaocara & 719697 & 4293.37 & 19.76 & 0.38 \\
\hline & Campos dos Goytacazes & 289613 & 2301.88 & 23.38 & 0.29 \\
\hline & Highest MSR / Lowest MSR & 2.49 & & & \\
\hline \multirow[t]{3}{*}{ GY } & Itaocara & 492657 & 3924.91 & 17.88 & 0.39 \\
\hline & Campos dos Goytacazes & 164950 & 2266.97 & 17.91 & 0.35 \\
\hline & Highest MSR / Lowest MSR & 2.99 & & & \\
\hline \multirow[t]{3}{*}{$\mathrm{PE}$} & Itaocara & 19.91 & 33.56 & 13.29 & 0.29 \\
\hline & Campos dos Goytacazes & 22.22 & 32.85 & 13.89 & 0.35 \\
\hline & Highest MSR / Lowest MSR & 1.12 & & & \\
\hline
\end{tabular}

$\mathrm{PH}=$ plant height $(\mathrm{m}) ; \mathrm{PR}=$ prolificacy; $100 \mathrm{GW}=100$ grain weight $(\mathrm{g}) ; \mathrm{EW}=$ ear weight $\left(\mathrm{kg} \mathrm{ha}^{-1}\right) ; \mathrm{GY}=$ grain yield $\left(\mathrm{kg} \mathrm{ha}^{-1}\right) ; \mathrm{PE}=$ popping expansion $\left(\mathrm{mL} \mathrm{g}^{-1}\right)$; Highest MSR / Lowest MSR = test of homogeneity of variance according to Gomes and Garcia (2002).

The progeny as a source of variation significantly affected $(p<0.05)$ all characters evaluated (Table 2), indicating that there is sufficient genetic variability among the progenies to obtain gains in the next selection cycles. The environment as a source of variation had no significant effect $(p>0.05)$ only on the popping expansion, although this is a polygenic inheritance character (ZEIGLER, 2001). Therefore, there is a possible oligogenesis for this character, as described by Dofing, D'Croz-Mason and Buck (1991). The effect of the environment on the other characters were sufficiently distinct. This result was similar to those found by Ribeiro et al. (2012) and Freitas et al. (2014), which confirmed the representativeness of Campos dos Goytacazes, and Itaocara for the evaluation of progenies in recurrent selection.

The progeny-environment interactions did not significantly affected $(p>0.05)$ most of the characters evaluated (Table 2), especially the popping expansion. Thus, the ranking of a progeny performance in an environment tends to be the same in other environment. Consequently, a single environment can be considered for selection purposes. This information is important because recurrent selection process conducted in a single environment have lower costs. These results confirm those found by Santos et al. (2008) and Freitas et al. (2014), however, Freitas Júnior et al. (2009), Rangel et al. (2011) and Ribeiro et al. (2012) reported significant interaction for popping expansion due to progeny-environment interactions.

The coefficient of variation of the experiment (CVe) ranged from 9.60 to $21.87 \%$, with the $\mathrm{PH}, \mathrm{GY}$ and PE characters expressing CVes below 20\% (Table 2), which represents a good precision (GOMES, 2000). Faria et al. (2008) evaluated the efficiency of reciprocal recurrent selection in popcorn hybrids and found higher $\mathrm{CV}$ estimates than those of the present study, for both GY $(20.90 \%)$ and PC (16\%). Although low, the CVes were higher than CVgs, resulting in estimates of Iv below 1.0. 
A. G. GUIMARÃES et al.

Table 2. Joint analysis of variance and genetic parameters of six characters of the UENF-14 popcorn population in the eighth recurrent selection cycle in two environments.

\begin{tabular}{cccccccc}
\hline & & \multicolumn{5}{c}{ Mean Squares } \\
\cline { 3 - 8 } Source of Variation & DF & PH & PR & $100 \mathrm{GW}$ & EW & GY & PE \\
\hline Block/Environment & 4 & 0.8 & 0.41 & 23.07 & 5595628.7 & 4031093 & 607.84 \\
Progeny (P) & 199 & $0.07^{* *}$ & $0.16^{*}$ & $10.41^{*}$ & $947532.7^{* *}$ & $618255.6^{* *}$ & $37.97^{* *}$ \\
Environment (E) & 1 & $72.67^{* *}$ & $40.46^{* *}$ & $5188.02^{* *}$ & $1189805683^{* *}$ & $824625915.4^{* *}$ & $2562.47^{\text {ns }}$ \\
P x E & 199 & $0.03^{\text {ns }}$ & $0.08^{\text {ns }}$ & $5.90^{\text {ns }}$ & $630521.5^{*}$ & $443785.5^{*}$ & $20.61^{\text {ns }}$ \\
Residue & 796 & 0.03 & 0.08 & 5.64 & 504655.6 & 328803.9 & 21.05 \\
\hline Mean & & 1.65 & 1.27 & 11.64 & 3297.62 & 3095.95 & 33.20 \\
\hline Parameters & & & & & & & 7.09 \\
\hline CVg & - & 5.02 & 9.33 & 7.65 & 8.23 & 18.52 & 13.05 \\
CVe & - & 9.60 & 21.87 & 20.40 & 21.54 & 0.38 & 0.35 \\
Iv & - & 0.52 & 0.42 & 0.37 & 0.38 & 0.47 & 0.44 \\
h & - & 0.62 & 0.52 & 0.46 & 0.47 & & \\
\hline
\end{tabular}

$\mathrm{DF}=$ degrees of freedom; $\mathrm{CVg}=$ coefficient of genetic variation (\%); $\mathrm{CVe}=$ coefficient of variation of the experiment $(\%) ; \mathrm{Iv}=$ Variation index; $\mathrm{h}^{2}=$ heritability based on the progeny averages; ${ }^{\mathrm{ns}}=$ not significant, ${ }^{* *}=$ significant at $p<0.01$, and ${ }^{*}=$ significant at $p<0.05$ by the $\mathrm{F}$ teste. $\mathrm{PH}=$ plant height $(\mathrm{m}) ; \mathrm{PR}=$ prolificacy; $100 \mathrm{GW}=100$ grain weight $(\mathrm{g})$; $\mathrm{EW}=$ ear weight $\left(\mathrm{kg} \mathrm{ha}^{-1}\right) ; \mathrm{GY}=$ grain yield $\left(\mathrm{kg} \mathrm{ha}^{-1}\right) ; \mathrm{PE}=$ popping expansion $\left(\mathrm{mL} \mathrm{g}^{-1}\right)$.

All characters showed heritability estimates $\left(\mathrm{h}^{2}\right)$ of average magnitude, between $44 \%(\mathrm{PE})$ and $62 \%(\mathrm{PH})$. Similar $\mathrm{h}^{2}$ were reported by Faria et al. (2008), with values of $50.37 \%$ for GY and $60.48 \%$ for EC. Therefore, considering the average magnitude of the $\mathrm{h}^{2}$, recurrent selection is the most adequate alternative to obtain higher gains, compared to simpler selection methods.

Estimates of phenotypic and genetic correlations in the eighth cycle of the UENF-14 population

Correlation estimates allow the evaluation of the association level between two characters and the feasibility of indirect selection by selecting a single character that result in simultaneous changes in one or more characters of agronomic importance. However, the interpretation of these estimates must be carried out carefully, since they are complexed by the meaning and different importance of the characters, by the effect of two or more characters, and by the effect of the environment on their expression (FALCONER; MACKAY, 1996). The estimates of the phenotypic correlation coefficients of most variables evaluated were significance at $1 \%$ probability for EW and GY. Although the absolute values of the genotypic correlations, in general, were superior to the phenotypic ones, they did not show significance in any of the pairs of characters evaluated (Table 3 ).

Table 3. Phenotypic $(\mathrm{rF})$ and genotypic ( $\mathrm{rG}$ ) correlations among six agronomic characters evaluated in 200 full-sibling progenies in the eighth recurrent selection cycle of the UENF-14 popcorn population.

\begin{tabular}{|c|c|c|c|c|c|c|}
\hline & & PR & $100 \mathrm{GW}$ & EW & GY & $\mathrm{PE}$ \\
\hline \multirow[t]{2}{*}{$\mathrm{PH}^{(1)}$} & $\overline{r_{F}}$ & $0.06^{\mathrm{ns}}$ & $0.25 * *$ & $0.26^{\mathrm{ns}}$ & $0.21^{\mathrm{ns}}$ & $0.14^{*}$ \\
\hline & $\mathrm{r}_{\mathrm{G}}$ & $-0.22^{\mathrm{ns}}$ & $0.37^{\mathrm{ns}}$ & $0.47^{\mathrm{ns}}$ & $0.40^{\mathrm{ns}}$ & $0.38^{\mathrm{ns}}$ \\
\hline \multirow{2}{*}{ PRL } & $\mathrm{r}_{\mathrm{F}}$ & & $-0.14^{\mathrm{ns}}$ & $0.41 * *$ & $0.41 * *$ & $-0.10^{\mathrm{ns}}$ \\
\hline & $r_{G}$ & & $-0.33^{\text {ns }}$ & $0.43^{\mathrm{ns}}$ & $0.49^{\mathrm{ns}}$ & $-0.15^{\mathrm{ns}}$ \\
\hline \multirow{2}{*}{$100 \mathrm{GW}$} & $\mathrm{r}_{\mathrm{F}}$ & & & $0.25^{* *}$ & $0.23 * *$ & $0.12^{\mathrm{ns}}$ \\
\hline & $r_{G}$ & & & $0.39^{\mathrm{ns}}$ & $0.38^{\mathrm{ns}}$ & $0.15^{\text {ns }}$ \\
\hline \multirow{2}{*}{ EW } & $r_{F}$ & & & & $0.93 * *$ & $0.03^{\mathrm{ns}}$ \\
\hline & $\mathrm{r}_{\mathrm{G}}$ & & & & $0.95^{\mathrm{ns}}$ & $0.03^{\mathrm{ns}}$ \\
\hline \multirow{2}{*}{ GY } & $\mathrm{r}_{\mathrm{F}}$ & & & & & $0.04^{\mathrm{ns}}$ \\
\hline & $r_{G}$ & & & & & $0.03^{\mathrm{ns}}$ \\
\hline
\end{tabular}

$\mathrm{PH}=$ plant height $(\mathrm{m}) ; \mathrm{PR}=$ prolificacy; $100 \mathrm{GW}=100$ grain weight $(\mathrm{g}) ; \mathrm{EW}=$ ear weight $\left(\mathrm{kg} \mathrm{ha}^{-1}\right) ; \mathrm{GY}=$ grain yield $\left(\mathrm{kg} \mathrm{ha}^{-1}\right) ; \mathrm{PE}=$ popping expansion $\left(\mathrm{mL} \mathrm{g}^{-1}\right) ;{ }^{\mathrm{ns}}=$ not significant, $\stackrel{* *}{=}$ significant at $p<0.01$, and ${ }^{*}=$ significant at $p<0.05$ by the $\mathrm{F}$ teste.

Although the correlation between GY and PE was positive, it was not significant and had low magnitude (0.04). In most cases, this correlation is null or negative (HALLAUER, 2001; RANGEL et al., 2011; CABRAL et al., 2016). Different from PE, the phenotypic correlations of GY with most variables were high, positive, and significant. This indicates that increases in prolificacy (PR), 100-grain weight $(100 \mathrm{GW})$ and ear weight $(\mathrm{EW})$ can result in more productive popcorn genotypes. The use of the selection index is justified by the low correlation of the grain popping expansion with the other 
characters evaluated, since it allows simultaneous genetic gains, even with adverse effects characteristics (RANGEL et al., 2011; CRUZ; REGAZZI; CARNEIRO, 2012) on the two main characteristics of interest to the producer and consumer-grain yield and popping expansion, respectively. Therefore, it is possible to gather superior genotypes for a set of characters, regardless of the correlations between characteristics (AMARAL JÚNIOR et al., 2010; CRUZ; REGAZZI; CARNEIRO, 2012).

Genetic gains and potential progenies in the eighth selective cycle of the UENF-14 popcorn population
The genetic parameters previously estimated in the joint analysis of variance were used to predict the genetic gains of the characters used in the Mulamba and Mock (1978) selection index for the selection of thirty superior progenies (Table 4). This index is also known as the rank sum index and consists in summing the number that the genotype presents for each character according to its rank, classified in a favorable (superior or inferior) order for improvement. The proposed direction was superior for PE and GY, and inferior for the other characters - the lower the value obtained, the better the rating. Thus, once classified, the orders of each genotype for each character are added (CRUZ; REGAZZI; CARNEIRO, 2012) until selecting the thirty best progenies.

Table 4. Estimates of percentage gains obtained by different economic weights by the selection index of Mulamba and Mock in the eighth recurrent selection cycle of the UENF-14 popcorn population.

\begin{tabular}{cccccr}
\hline \multirow{2}{*}{ Character } & \multicolumn{5}{c}{ Mulamba and Mock (\%) } \\
\cline { 2 - 6 } & $\mathrm{SDg}$ & $\mathrm{CVg}$ & $\mathrm{Iv}$ & $\mathrm{h}^{2}$ & WA \\
\hline PH & 2.03 & 1.28 & 0.07 & 0.13 & 1.81 \\
PR & 5.56 & 7.00 & 5.56 & 5.48 & 2.66 \\
$100 \mathrm{GW}$ & 0.99 & 2.36 & 2.54 & 2.71 & 1.64 \\
EW & 9.33 & 8.01 & 4.84 & 4.78 & 5.34 \\
GY & 7.76 & 6.83 & 3.88 & 3.68 & 4.60 \\
PE & 0.44 & 1.30 & 1.46 & 1.93 & 3.61 \\
\hline
\end{tabular}

$\mathrm{PH}=$ plant height $(\mathrm{m}) ; \mathrm{PR}=$ prolificacy; $100 \mathrm{GW}=100$ grain weight $(\mathrm{g}) ; \mathrm{EW}=$ ear weight $\left(\mathrm{kg} \mathrm{ha}^{-1}\right) ;$ $\mathrm{GY}=$ grain yield $\left(\mathrm{kg} \mathrm{ha}^{-1}\right) ; \mathrm{PE}=$ popping expansion $\left(\mathrm{mL} \mathrm{g}^{-1}\right) ; \mathrm{SDg}=$ genotypic standard deviation; $\mathrm{CVg}=$ coefficient of genetic variation; Iv = Variation index; $\mathrm{h}^{2}=$ heritability; and $\mathrm{WA}=$ weights assigned by attempts - 0 (PH), 1 (PR), 1 (100GW), 1 (EW), 5 (GY), and $10(\mathrm{PE})$.

The use of the economic weight genotypic standard deviation (SDg) had the highest percentage gains for EW (9.33\%), GY (7.76\%) and PH (2.03\%). However, this estimator should not be used due to the high gain for plant height, since increases in this character are not desirable. Increases in plant height can favor lodging due to the strong winds that occur in the regions evaluated. Moreover, the SDg had the lowest percentage gain for PE $(0.44 \%)$.

The coefficient of genetic variation $(\mathrm{CVg})$ allows the breeder to have a real notion of the existing genetic variability. It is direct related to the genetic variance of the population and results in a more accurate selection of the superior progenies. In this attempt, although the use of $\mathrm{CVg}$ as economic weight resulted in high gains for EW (8.01\%), PR $(7.00 \%)$, and GY $(6.83 \%)$, it was not advantageous for considerable gains in popping expansion, showing the second lowest estimate (1.30\%). Therefore, it should not be considered as a superior selective parameter.

The variation found for the estimation of the economic weights Iv and $\mathrm{h}^{2}$ resulted in reduced gains for the $\mathrm{PH}$-estimates of $0.07 \%$ and $0.13 \%$, respectively. This result is of interest for the UENF's Popcorn Breeding Program, which aims to favor the tolerance to the lodging, due to the strong winds that occur in the North and Northwest regions of the state of Rio de Janeiro. However, estimate gains for the characters EW, GY, and PE were lower than those obtained by using the weights assigned by attempts (WA).

The WA resulted in the largest gains for $\mathrm{PE}$ $(3.61 \%)$, and intermediate, but desirable gains, for the remaining characters. Thus, the arbitrary weights favored simultaneous gains in PE and GY and broke the negative correlation between them, which are the main characters of economic importance of this crop. This indicates that most of this correlation is due to gene binding, which can be broken with recombination after each selection cycle.

Amaral Júnior et al. (2016) found values close to predicted genetic gains using data from the present work through Bayesian analysis, with gains of $4.3 \%$ for GY and $2.9 \%$ for PE. Therefore, the arbitrary weights were the more suitable method for the selection of the thirty progenies that were reliably superior for recombination of the characters 
evaluated, favoring consistent gains for the next recurrent selection cycle. Similar results with the use of arbitrary weights were found by Arnhold and Viana (2007), Rangel et al. (2011), Ribeiro et al. (2012) and Freitas et al. (2014).

Genetic progress in the selective cycles of the UENF -14 popcorn population.

The predicted means for the selection of the thirty progenies of full-siblings in the eighth cycle through the economic weights assigned by attempts were used to estimate the genetic progress compared to the means of the controls of UENF-14 population (Figures 1A and 1B). GY increased $111.99 \mathrm{~kg} \mathrm{ha}^{-1}$ and PE increased $1.75 \mathrm{~mL} \mathrm{~g}^{-1}$, per cycle. Thus, the grain yield of $2,999.24 \mathrm{~kg} \mathrm{ha}^{-1}$ in the fourth cycle, could be increased to $3,399.88 \mathrm{~kg} \mathrm{ha}^{-1}$ in the eighth cycle; and the popping expansion of $27.98 \mathrm{~mL} \mathrm{~g}^{-1}$ in the fourth cycle could reach $35.89 \mathrm{~mL} \mathrm{~g}^{-1}$ after the progeny recombination in the eighth recurrent selection cycle (Figures 1A and 1B).
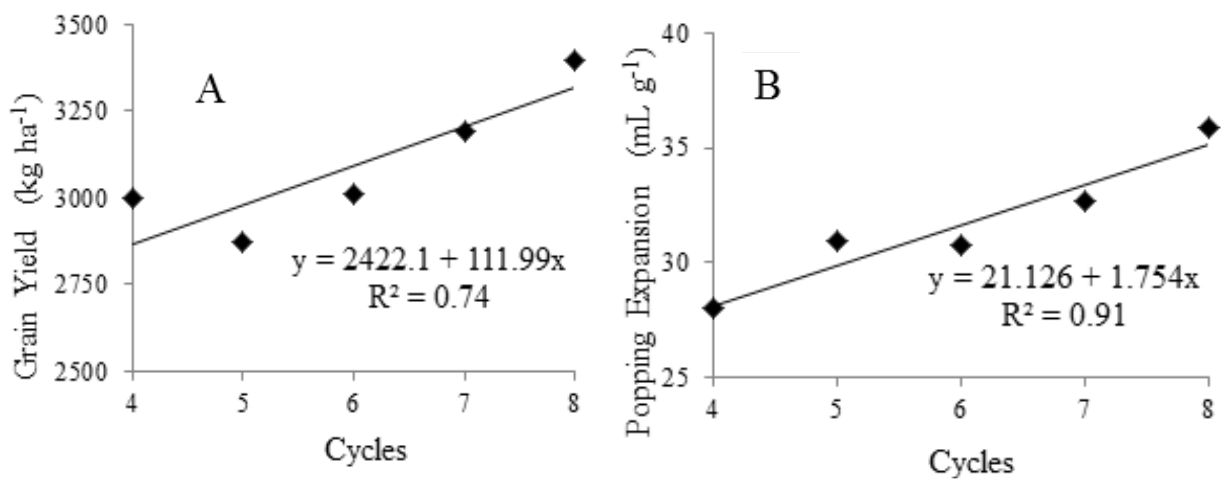

Figure 1. Grain yield $\left(\mathrm{kg} \mathrm{ha}^{-1}\right)(\mathrm{A})$ and popping expansion $\left(\mathrm{mL} \mathrm{g}^{-1}\right)(\mathrm{B})$ averages in the $\mathrm{C} 4, \mathrm{C} 5, \mathrm{C} 6, \mathrm{C} 7$ cycles, and predicted averages for the $\mathrm{C} 8$ cycle.

The progressive evolution of satisfactory results obtained in this work and the predicted results for the other cycles confirm the efficiency of intra-population recurrent selection in gradually increase the concentration of favorable alleles for GY and PE (PEREIRA; AMARAL JÚNIOR, 2001; RIBEIRO et al., 2012; FREITAS et al., 2014). They also indicate the possibility of obtaining a new crop variety superior to that released in 2013, after five selective cycles, (UENF-14) and recommended for the producers of the North and Northwest regions of the state of Rio de Janeiro (AMARAL JÚNIOR et al., 2013).

\section{CONCLUSIONS}

Gains of $3.6 \%$ for popping expansion and $4.6 \%$ for grain yield are expected in the eighth cycle of recurrent selection of the UENF-14 popcorn population, when economic weights assigned by attempts is used. This indicates the possibility of substantial gains from the use of selection indices. The average gain between cycles 4 and 8 (3.34\% for grain yield and $7.06 \%$ for popping expansion) also confirms this possibility and the prediction of success in the continuity of recurrent selection.

\section{REFERENCES}

AMARAL JÚNIOR, A. T. et al. Improvement of a popcorn population using selection indexes from a fourth cycle of recurrent selection program carried out in two different environments. Genetics and Molecular Research, Ribeirão Preto, v. 9, n. 1, p. 340-370, 2010.

AMARAL JÚNIOR, A. T. et al. UENF 14: a new popcorn cultivar. Crop Breeding and Applied Biotechnology, Viçosa, v. 13, n. 3, p. 218-220, 2013.

AMARAL JÚNIOR, A. T. et al. Bayesian analysis of quantitative traits in popcorn (Zea mays L.) through four cycles of recurrent selection. Plant Production Science, Tóquio, v. 19, n. 4, p. 1-5, 2016.

ARNHOLD, E.; VIANA, J. M. S. Eficiência da seleção dentro de famílias S4 de milho-pipoca, visando à obtenção de linhagens. Revista Ceres, Viçosa, v. 54, n. 312, p. 107-111, 2007.

CABRAL, P. D. S. et al. Relação de causa e efeito de caracteres quantitativos sobre a capacidade de expansão do grão em milho-pipoca. Revista Ciência Agronômica, Fortaleza, v. 47, n. 1, p. 108-117, 2016.

CRUZ, C. D. Genes: a software package for analysis in experimental statistics and quantitative genetics. Acta Scientiarum Agronomy, Maringá, v. 35, n. 3, p. 271-276, 2013.

CRUZ, C. D.; REGAZZI, A. J.; CARNEIRO, P. C. $\mathrm{S}$. Modelos biométricos aplicados ao 
melhoramento genético. 4. ed. Viçosa, MG: UFV, 2012.514 p.

DOFING, S. M.; D’CROZ-MASON, N.; BUCK, J. $\mathrm{S}$. Inheritance of expansion volume and yield in two popcorn $\times$ dent corn crosses. Crop Science, Madison, v. 31, n. 3, p. 715-718, 1991.

FALCONER, D. S.; MACKAY, T. F. C. Introduction to quantitative genetics. 4. ed. Harlow: Longman, 1996. 464 p.

FARIA, V. R. et al. Seleção recorrente recíproca na obtenção de híbridos interpopulacionais de milho pipoca. Pesquisa Agropecuária Brasileira, Brasília, v. 43, n. 12, p. 1749-1755, 2008.

FREITAS JÚNIOR, S. P. et al. Genetic gains in popcorn by full-sib recurrent selection. Crop Breeding and Applied Biotechnology, Viçosa, v. 9, n. 1, p. 1-7, 2009.

FREITAS, I. L. J. et al. Genetic gains in the UENF14 popcorn population with recurrent selection. Genetics and Molecular Research, Ribeirão Preto, v. 13, n. 1, p. 518-527, 2014.

GOMES, F. P. Curso de Estatística Experimental. 14. ed. Piracicaba, SP: ESALQ, 2000. 477 p.

GOMES, F. P.; GARCIA, C. H. Estatística aplicada a experimentos agronômicos e florestais. 1. ed. Piracicaba, SP: FEALQ, 2002. 309 p.

HALlAUER, A. R. Specialty corns. 2. ed. Boca Raton, FL: CRC Press, 2001, 496 p.

HALLAUER, A. R.; CARENA, M. J. Maize. In: CARENA, M. J. (Ed.). Handbook of Plant Breeding: Cereals. New York: Springer, 2009. v. 3, cap. 2, p. 3-98.

HALLAUER, A. R.; MIRANDA FILHO, J. B.; CARENA, M. J. Testers and combining ability. In: PROHENS, J.; NUEZ, F.; CARENA, M. J. (Eds.). Handbook of plant breeding: Quantitative genetics in maize breeding, New York: Springer, 2010. v. 6, cap. 8 , p. 383-423.

MULAMBA, N. N.; MOCK, J. J. Improvement of yield potential of the Eto Blanco maize (Zea mays L.) population by breeding for plant traits. Egyptian Journal of Genetics and Cytology, Alexandria, v. 7, n. 1, p. $40-51,1978$

PEREIRA, M. G.; AMARAL JÚNIOR, A. T. Estimation of genetic components in popcorn based on the nested design. Crop Breeding and Applied Biotechnology, Viçosa, v. 1, n. 1, p. 3-10, 2001.
RAMALHO, M. A. P. et al. Aplicações da genética quantitativa no melhoramento de plantas autógamas. 1. ed. Lavras, MG: UFLA, 2012. 522 p.

RANGEL, R. M. et al. Análise biométrica de ganhos por seleção em população de milho pipoca de quinto ciclo de seleção recorrente. Revista Ciência Agronômica, Fortaleza, v. 42, n. 11, p. 473-481, 2011 .

RIBEIRO, E. H. et al. Estimativas de parâmetros genéticos e seleção de linhagens endogâmicas recombinantes. Revista Ceres, Viçosa, v. 56, n. 5, p. 580-590, 2009

RIBEIRO, R. M. et al. Genetic progress in the UNB$2 \mathrm{U}$ population of popcorn under recurrent selection in Rio de Janeiro. Genetics and Molecular Research, Ribeirão Preto, v. 11, n. 2, p. 1417-1423, 2012.

SANTOS, F. S. et al. Predição de ganhos genéticos por índices de seleção na população de milho pipoca UNB-2U sob seleção recorrente. Bragantia, Campinas, v. 66, n. 3, p. 389-396, 2007.

SANTOS, F. S. et al. Genetic gain prediction of the third recurrent selection cycle in a popcorn population. Acta Scientiarum Agronomy, Maringá, v. 30, Sup., p. $651-655,2008$

SAWAZAKI, E. A cultura do milho pipoca no Brasil. O Agronômico, Campinas, v. 53, n. 2, p. 1113, 2001.

ZEIGLER, K. E. Popcorn. In: HALLAUER, A. R. (Ed.). Specialty Corns. Boca Raton, FL: CRC Press, 2001. v. 2, cap. 7, p. 199-234. 